\title{
PEMANFAATAN PROGRESS TEST SEBAGAI TOLAK UKUR KEBERHASILAN BELAJAR MAHASISWA
}

\author{
Mirfat*, Yuhernita** \\ *Bagian Anatomi, Fakultas Kedokteran Universitas Yarsi \\ **Bagian Biokimia, Fakultas Kedokteran Universitas Yarsi
}

\begin{abstract}
Background: Faculty of Medicine, YARSI University has experienced a paradigm shift in higher education from a content-based curriculum to a competency-based curriculum that has been applied since the academic year of 2007/ 2008 using a problem-based learning approach. Progress test is an evaluation that is used to measure the student's competency in the field of knowledge in its entirety. Faculty of Medicine, YARSI University has yet to apply these progress test. Thus, this research is aimed to execute a progress test trial in attempt to use it as a standard measurement to observe student capabilities in the field of knowledge, either as the individual or as a whole class.

Method: This research uses a qualitative method. The research sample consists of 200 students from the faculty of medicine chosen by using a randomized approach for each class, starting from the class of 2013 (first year students) until the class of 2010 (fourth year students).

Results: Based on student entrance levels in years, $4^{\text {th }}$ year students had acquired a higher score on the progress test trial in comparison to the $1^{\text {st }}, 2^{\text {nd }}$ and $3^{\text {rd }}$ year students. The results had also shown that the students in their first year of study had lower scores when compared to the students in their last year of study (4th year). This indicates that the longer the period of study or the more time spent in the study process, the better the scores achieved on the progress test.

Conclusion: Faculty of Medicine, YARSI University has successfully executed the progress test trial in the first week of the third block in the odd semester of the academic year of 2013/2014. The progress test itself consisted of 200 questions and was taken by 200 student samples that were chosen in a randomized manner. The results of the progress test had revealed that there was an increase in the average examination grades of students in the $1^{\text {st }}$ year until the $4^{\text {th }}$ year, which is consistent with the level of understanding of lectures accordingly to each year. Item Analysis on the test showed a good distribution in the level of difficulty, where the majority of questions were beld in the moderate level of difficulty.
\end{abstract}

Keywords: progress test

\section{ABSTRAK}

Latar Belakang : Fakultas Kkedokteran Universitas Yarsi (FK UY) telah mengalami perubahan paradigma pendidikan tinggi, dari kurikulum yang berbasis isi atau content-based curriculum menuju kurikulum yang berbasis kompetensi atau competency-based curriculum yang telah dilaksanakan sejak Tahun Akademik 2007/2008 dengan metode pembelajaran Problem Based Learning. Progress Test adalah evaluasi yang dapat digunakan untuk mengukur kemampuan mahasiswa dari ranah Knowledge secara keseluruhan, namun FK UY belum pernah melaksanakan Progress Test. Oleh karena itu, penelitian ini bertujuan untuk melakukan uji coba pelaksanaan Progress test sebagai tolak ukur untuk melihat perkembangan kemampuan pengetahuan mahasiswa baik secara individu maupun angkatan.

Metode: Penelitian ini menggunakan metode kualitatif. Subyek penelitian terdiri dari 200 mahasiswa fakultas kedokteran yang dipilih secara random setiap angkatan, mulai dari angkatan 2010-2013.

Hasil: Perolehan nilai tertinggi progress test berdasarkan tingkatan tahun angkatan terlihat bahwa tahun 4 yang merupakan mahasiswa tahun terakhir lebih tinggi dibandingkan tahun 3, 2 dan 1 . Hasil progress test tersebut juga memperlihatkan bahwa mahasiswa di tahun pertama nilainya lebih rendah dibandingkan mahasiswa tahun terakhir.

Korespondensi: mirfat@yarsi.ac.id ; No.HP: 085213932784 
Hal ini menunjukkan bahwa semakin lama masa studi mahasiswa dalam mengikuti proses belajar maka nilai progress test yang dicapai akan semakin baik.

Kesimpulan: Progress test telah berhasil dilaksanakan di FK UY pada minggu pertama blok ketiga semester ganjil TA 2013/2014. Progress test yang terdiri dari 200 soal, diikuti oleh 200 mahasiswa yang dipilih secara random. Hasil progress test menunjukan adanya peningkatan nilai rata-rata ujian dari mahasiswa Tahun 1 sampai Tahun 4 yang konsisten dengan tingkat pemahaman materi kuliah setiap angkatannya. Analisis butir soal menunjukan sebaran tingkat kesukaran yang cukup baik, sebagian besar berada dalam level sedang.

Kata kunci: progress test

\section{PENDAHULUAN}

Fakultas Kedokteran Universitas YARSI (FK-UY) telah mengalami perubahan paradigma pendidikan tinggi, dari kurikulum yang berbasis isi atau content-based curriculum menuju kurikulum yang berbasis kompetensi atau competency-based curriculum. Perubahan kurikulum yang berbasis kompetensi ini sudah dilaksanakan sejak tahun akademik 2007/2008 dengan metode pembelajaran problem-based learning. Metode ini memberikan nilai tambah bagi mahasiswa karena mahasiswa melakukan diskusi tutorial berdasarkan kasus-kasus medis yang harus diselesaikan dan dijawab oleh mahasiswa dengan bimbingan dosen sebagai tutornya. Dengan metode ini maka keaktifan dan kemandirian mahasiswa untuk belajar menjadi faktor yang sangat penting.

Metode pengajaran pada Fakultas Kedokteran Universitas YARSI ditekankan pada tiga ranah yaitu pengetahuan, afektif dan psikomotor. Pelaksanaan selama 6 minggu, dengan 2 tahapan aktivitas pembelajaran, yaitu tahap proses belajar dan tahap umpan balik. Proses belajar berupa kuliah interaktif, belajar dalam kelompok tutorial, belajar dalam laboratorium (praktikum), keterampilan klinik dasar, dan penugasan mandiri.

Evaluasi hasil belajar mahasiswa terdiri atas evaluasi formatif dan sumatif. Hasil evaluasi formatif pada Fakultas Kedokteran Universitas YARSI tidak mempengaruhi nilai mahasiswa namun menjadi prasyarat untuk mengikuti ujian akhir blok. Evaluasi sumatif didasarkan pada nilai penugasan, nilai rangkuman diskusi tutorial, ujian praktikum dan ujian akhir Blok.

Berbagai tujuan dan peran assessment yang digunakan di seluruh sistem pendidikan yang ada, yang paling diakui adalah evaluasi hasil belajar melalui summative assessment. ${ }^{1}$ Tetapi assessment formatif juga diperlukan sebagai tolak ukur untuk mengarahkan mahasiswa terhadap pengetahuan yang telah mereka peroleh serta dapat memperkuat motivasi intrinsik mahasiswa untuk belajar dan menginspirasi mereka untuk menetapkan standar yang lebih tinggi bagi mereka. ${ }^{2}$

Pada tahun 2011, Manoppo melaporkan bahwa di Fakultas Kedokteran Universitas Sam Ratulangi, penilaian formatif pada mahasiswa FK UNSRAT mempengaruhi hasil penilaian sumatif secara bermakna. Penilaian formatif yang dilakukan berkesinambungan dapat meningkatan hasil akhir pada ujian sumatif mahasiswa. ${ }^{3}$ Berdasarkan hasil pengamatan kami ternyata kualitas dan kuantitas belajar mahasiswa sangat dipengaruhi oleh ujian karena mahasiswa lebih terpacu untuk belajar pada saat akan mengikuti ujian.

Pendidikan pada fakultas kedokteran di seluruh dunia bertujuan menghasilkan lulusan dokter yang kompeten dan mampu melayani masyarakat serta memajukan bidang kedokteran. Kompetensi diperoleh melalui pengembangan dan integrasi dari tiga domain utama: kognitif, psikomotorik dan afektif. Sebuah kurikulum yang dirancang dengan baik harus menjamin tercapainya kompetensi ini melalui penyediaan instruksi efektif, sumber daya yang memadai dan student assessment yang tepat. ${ }^{4}$ Dengan demikian student assessment menjadi salah satu tolak ukur yang penting untuk menjamin proses belajar mengajar yang telah dilaksanakan berjalan dengan baik.

Hasil belajar mahasiswa perlu dievaluasi untuk memberi gambaran keberhasilan belajar mahasiswa. Selama ini pelaksanaan ujian formatif kurang efektif karena terdapat beberapa kendala dan kekurangan diantaranya adalah ujian formatif selama ini hanya mengukur penguasaan materi blok tertentu, tempat duduk peserta ujian sangat 
berdekatan sehingga memberi peluang untuk mencontek. Selain itu umpan balik yang diberikan tidak optimal karena tidak semua pengampu dapat hadir pada saat ujian formatif dilaksanakan sedangkan mahasiswa membutuhkan pemahaman tentang materi blok yang masih belum dikuasai dengan jelas, ditambah lagi ujian formatif tidak pernah dievaluasi.

Untuk itu perlu adanya alat ukur yang dapat mengevaluasi penguasaan materi secara keseluruhan, tidak hanya satu blok tertentu saja. Progress Test adalah evaluasi yang dapat digunakan untuk mengukur kemampuan mahasiswa dari ranah knowledge secara keseluruhan.

\section{METODE}

Penelitian ini menggunakan metode kualitatif. Jenis penelitian ini merupakan penelitian non eksperimen dengan rancangan penelitian deskriptif. Subyek penelitian terdiri dari 200 mahasiswa fakultas kedokteran yang dipilih secara acak untuk setiap angkatan, mulai dari angkatan 2013 sampai dengan angkatan 2010. Berikut tahapan pelaksanaan progress test:

1. Pembuatan soal - soal ujian diperoleh melalui pengampu di blok terkait dan koordinator blok yang mengkoordinir pengumpulan soal dari pengampu dalam blok yang bersangkutan. Soal yang diperoleh dari pengampu dan koordinator blok kemudian dikumpulkan, direview dan dipilih sehingga diperoleh 200 soal yang dapat mewakili semua blok yang ada di FK UY. Kemudian soal disusun menjadi satu set naskah soal ujian.

2. Pengaturan alokasi ruang ujian dan pengawas ujian - ruang ujian yang dipakai adalah ruang kuliah lantai 6 sampai dengan lantai 10. Jumlah mahasiswa dalam setiap ruangan di atur sehingga jarak setiap mahasiswa tidak kurang dari $1 \mathrm{~m}$. Jumlah pengawas yang digunakan sesuai dengan perbandingan 1 pengawas untuk 25-30 mahasiswa, sehingga untuk 200 mahasiswa dibutuhkan $+8-10$ pengawas.

3. Penggandaan soal - naskah soal yang sudah jadi kemudian digandakan sebanyak 200 exemplar dan dikemas dalam amplop sesuai dengan pembagian ruang ujian mahasiswa. Naskah ujian kemudian disimpan ditempat yang aman sampai saat ujian dilaksanakan.

4. Pelaksanaan progress test - progress test telah dilaksanakan pada minggu pertama Blok ketiga semester ganjil. Diikuti oleh 200 orang mahasiswa UY tahap Akademik yang dipilih secara random.

5. Koreksi hasil progress test - lembar Jawaban mahasiswa dikoreksi dengan menggunakan DMR scanner dan dipilah berdasarkan angkatan mahasiswa.

6. Analisa hasil progress test - hasil progress test dianalisa untuk mendapatkan gambaran pencapaian hasil belajar setiap angkatan dalam tahap akademik.

Sebelum progress test dilaksanakan, peneliti menjelaskan maksud dan tujuan dari penelitian ini kepada semua mahasiswa FK UY mulai dari angkatan 2013 sampai dengan angkatan 2010 dan mahasiswa yang dipilih sebagai subjek penelitian sudah menyetujui untuk mengikuti progress test. Ini merupakan uji coba pelaksanaan progress test di FKUY sebelum implementasi pada kurikulum 2014.

\section{HASIL DAN PEMBAHASAN}

Pada awalnya direncanakan bahwa mahasiswa yang mengikuti penelitian ini adalah seluruh mahasiswa FK UY, namun karena adanya kendala waktu pelaksanaan yang bertepatan dengan kegiatan rutin akademik maka hal diatas tidak dapat peneliti laksanakan. Hal ini merupakan salah satu kelemahan dalam pelaksanaan penelitian.

Naskah soal progress test terdiri dari 200 soal dengan format mengacu pada format naskah UKDI. Sebaran soal dalam naskah progress test ini disesuaikan dengan jumlah SKS blok-blok yang ada di KBK 2007. Jumlah soal yang berhasil dikumpulkan dari dosen pengampu dan Koordinator Blok adalah 300 soal. Dari review terhadap 300 soal oleh tim reviewer diperoleh 226 soal yang lolos review. Soal inilah yang kemudian dipilih dan disusun menjadi naskah soal progres test.

Mahasiswa yang mengikuti penelitian ini adalah mahasiswa FK UY, yaitu sebanyak 200 mahasiswa yang dipilih secara random mulai dari mahasiswa tahun 
pertama sampai mahasiswa tahun keempat. Mahasiswa tahun pertama adalah mahasiswa yang masuk pada tahun ajaran 2013/2014 yang selanjutnya disebut sebagai Tahun 1, mahasiswa tahun kedua adalah mahasiswa yang masuk pada tahun ajaran 2012/2013 yang selanjutnya disebut sebagai Tahun 2, mahasiswa tahun ketiga adalah mahasiswa yang masuk pada tahun ajaran yang selanjutnya disebut sebagai Tahun 3, sedangkan mahasiswa tahun keempat adalah mahasiswa yang masuk pada tahun ajaran 2010/2011 yang selanjutnya disebut sebagai Tahun 4. Masing-masing angkatan diambil sebanyak 50 mahasiswa secara random. Dari 200 mahasiswa yang mengikuti Progress Test tersebut 4 orang tidak hadir. Tabel 1 memperlihatkan nilai rata-rata progress test setiap angkatan, sedangkan gambar 1 memperlihatkan profil nilai progress test setiap angkatan peserta ujian.

Tabel 1. Nilai rata-rata hasil progress test Fakultas Kedokteran Universitas YARSI tahun ajaran 2013/2014

\begin{tabular}{ccc} 
No & Peserta & Nilai rata-rata \\
\hline 1 & Tahun 1 & $30,98 \pm 5,00$ \\
2 & Tahun 2 & $36,26 \pm 5,89$ \\
3 & Tahun 3 & $41,94 \pm 6,78$ \\
4 & Tahun 4 & $43,14+6,42$ \\
\hline
\end{tabular}

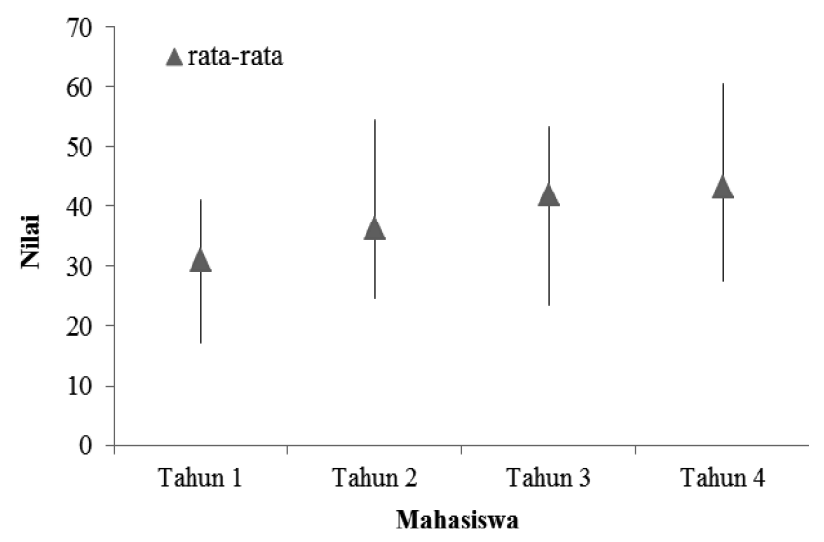

Gambar 1. Grafik hasil progress test pada keempat angkatan
Berdasarkan grafik pada gambar 1 dapat dilihat bahwa adanya kenaikan nilai rata-rata seiring lamanya masa studi mahasiswa. Jika dilihat dari sebaran nilai progress test diatas untuk mahasiswa tahun 1 jumlah mahasiswa yang mencapai nilai lebih tinggi dari nilai rata-rata ternyata lebih banyak dibandingkan mahasiswa dengan nilai di bawah rata-rata. Untuk mahasiswa tahun 2, jumlah mahasiswa yang mencapai nilai lebih tinggi dari nilai rata-rata lebih sedikit dibandingkan mahasiswa dengan nilai dibawah rata-rata. Untuk mahasiswa tahun 3, jumlah mahasiswa yang mencapai nilai lebih tinggi dari nilai rata-rata lebih banyak dibandingkan mahasiswa dengan nilai dibawah rata-rata. Jika dilihat dari hasil analisa soal, ternyata tingkat kesukaran dari soal progress test yang diberikan berada pada level rata-rata (78\%), sedangkan soal yang sukar hanya $17 \%$ dan soal yang mudah hanya $5 \%$. Dengan kondisi demikian mahasiswa tahun ketiga rata-rata lebih banyak dapat menjawab soalsoal progress test tersebut. Sedangkan untuk mahasiswa tahun 4, jumlah mahasiswa yang mencapai nilai lebih tinggi dari nilai rata-rata hampir sama jumlahnya dengan mahasiswa dengan nilai dibawah rata-rata.

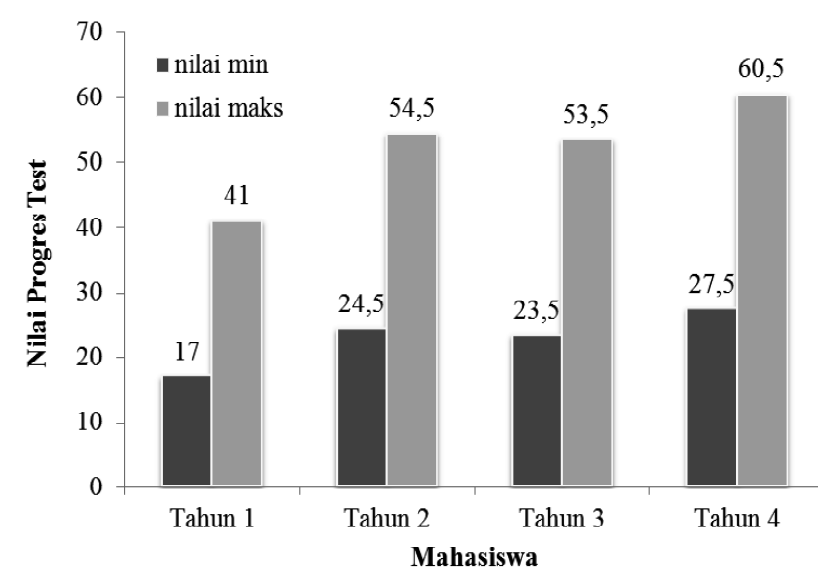

Gambar 2. Grafik sebaran skor progress test pada keempat angkatan

Berdasarkan grafik sebaran skor progress test pada keempat angkatan pada gambar 2 , nilai tertinggi progress test pada tahun 4 adalah 61, tahun 3 adalah 54, tahun 2 adalah 55 dan tahun 1 adalah 41. Perolehan nilai tertinggi progress test berdasarkan tingkatan tahun angkatan terlihat bahwa tahun 4 yang merupakan mahasiswa tahun terakhir lebih tinggi dibandingkan tahun 3, 2 dan 1 . Tabel 1 tersebut juga memperlihatkan bahwa mahasiswa 
di tahun pertama nilainya lebih rendah dibandingkan mahasiswa tahun terakhir.

Dalam penelitian ini juga dilakukan analisis terhadap butir soal yang digunakan dalam progress test. Tabel 2 memperlihatkan hasil analisis butir soal yang sudah dilakukan. Hasil analisis butir soal menunjukan bahwa tingkat kesukaran butir soal pada umumnya berada pada level sedang (70\%), sedangkan 20\% lainnya berada ada level sukar dan hanya $5 \%$ berada dalam level mudah .
Sedangkan dari distraktor yang digunakan dalam setiap butir soal didapatkan bahwa hampir semua distraktor dalam soal berfungsi dengan baik (96\%), hanya sebagaian kecil (4\%) yang perlu direvisi. Sementara itu dari daya beda setiap soal, didapatkan bahwa sebagian besar soal yang diberikan tidak mampu membedakan kelompok nilai tinggi dengan kelompok rendah rendah (55\%), sedangkan yang mempunyai daya beda yang baik hanyalah $17 \%$.

Tabel 2. Hasil analisis butir soal

\begin{tabular}{cclc} 
No & Analisis Butir Soal & Klasifikasi & Persentase \\
\hline 1 & Tingkat Kesukaran & Mudah & $4 \%$ \\
& & Sedang & $70 \%$ \\
\multirow{2}{*}{2} & \multirow{2}{*}{ Daya Beda } & Sukar & $26 \%$ \\
& & Jelek & $55 \%$ \\
& & Lemah & $16 \%$ \\
\multirow{2}{*}{3} & \multirow{2}{*}{ Distraktor } & Sedang & $13 \%$ \\
& & OK & $17 \%$ \\
4 & \multirow{2}{*}{ Jumlah soal : } & OK & $97 \%$ \\
& & Tidak OK & $4 \%$ \\
& & masuk bank soal & $17 \%$ \\
5 & \multirow{2}{*}{ Reabilitas Soal } & perlu dicek & $29 \%$ \\
\hline
\end{tabular}

Progress test pada ilmu kedokteran adalah suatu metode assessment dimana semua mahasiswa mengikuti ujian yang sama, dengan standar yang ditetapkan dari seorang dokter baru yang diharapkan berkualitas. Di Peninsula Medical School, setiap progress test yang diberikan terdiri dari 125 soal tipe pilihan berganda. Masing-masing soal terdiri dari clinical vignette, pertanyaan, dan 5 pilihan jawaban. ${ }^{5}$ Tipe soal yang sama juga dipakai pada progress test ini. Berdasarkan hasil yang dapat dilihat dari grafik pada Gambar 1, memperlihatkan bahwa mahasiswa tahun terakhir, yang sudah mendapatkan materi blok lebih banyak dibandingkan mahasiswa tahun 1, 2 dan 3 , sudah terbiasa dengan level knowledge yang diharapkan pada akhir program sarjana kedokteran.

Dengan mengikuti progress test diharapkan baik mahasiswa maupun dosen dapat memantau dan mengukur perkembangan kemampuan penalaran klinis mahasiswa dari tahun ke tahun selama mahasiswa menjalani proses pendidikan di tahap akademik. McHarg et al., ${ }^{6}$ menyatakan bahwa progress test tidak memungkinkan mahasiswa untuk menggunakan strategi perbaikan untuk ujian tertentu. Sebaliknya mahasiswa harus memperoleh informasi terus menerus dengan kata lain mereka harus belajar secara kontinyu. Progress test yang telah direview terlebih dahulu oleh dokter yang bertugas mereview soal-soal yang sesuai dengan standar kelulusan mahasiswa akan membantu mahasiswa menjadi terbiasa dengan tingkatan knowledge yang diharapkan pada tahun terakhir pendidikan.

Hasil penelitian ini menunjukkan bahwa semakin lama masa studi mahasiswa dalam mengikuti proses belajar maka nilai progress test yang dicapai juga akan semakin baik. Hal ini dapat dilihat dari grafik sebaran skor progress test pada keempat angkatan pada Gambar 2. Menaldi et al. pada penelitiannya di Fakultas Kedokteran Universitas Indonesia juga mendapatkan bahwa semakin lama 
mahasiswa mengikuti pendidikan, maka skor progress test yang diperoleh akan semakin baik. ${ }^{7}$

Berdasarkan hasil analisis terhadap butir soal yang digunakan dalam progress test memperlihatkan bahwa sebaran tingkat kesukaran soal yang cukup baik, dimana sebagian besar berada dalam level sedang. Hal ini disebabkan karena profil mahasiswa yang mengikuti ujian ini mempunyai rentang IPK yang kecil, sehingga tingkat penguasaan materi mahasiswa ini juga tidak jauh berbeda. Pada penelitian ini peserta yang dipilih mengikuti ujian ini dibatasi hanyalah mahasiswa yang telah mengikuti semua blok setiap tahunnya tanpa mengulang. Hal ini menjadi salah satu kelemahan dalam penelitian ini. Karena itulah secara keseluruhan reabilitas naskah soal juga menjadi kurang baik $\left(\mathrm{Kr}_{21}=0,71\right)$.

Setelah progress test dilaksanakan, peneliti melakukan diskusi dengan peserta progress test. Menurut mahasiswa Tahun 4, untuk materi blok pada semester awal sudah banyak terlupakan oleh mahasiswa. Hal ini menunjukkan bahwa kualitas dan kuantitas belajar mahasiswa sangat dipengaruhi oleh ujian karena mahasiswa lebih terpacu untuk belajar pada saat akan mengikuti ujian. Oleh karena itu pelaksanaan progress test setiap tahun di FK UY sangat diperlukan sehingga mahasiswa dapat memantau dan mengukur perkembangan proses belajar mereka dari tahun ke tahun selama mahasiswa menjalani proses pendidikan di tahap akademik, terutama di ranah pengetahuan. Hal ini sejalan dengan tujuan pelaksanaan progress test, dimana menurut McHarg et al., progress test adalah evaluasi yang digunakan secara berkala untuk memberikan penilaian sumatif dan formatif untuk mengetahui kemampuan mahasiswa dari ranah pengetahuan. ${ }^{2}$ Menaldi et al. menyatakan bahwa progress test sebagai salah satu cara untuk mengevaluasi dan menilai kemajuan belajar mahasiswa telah banyak dilakukan di berbagai institusi pendidikan dokter seperti di Fakultas Kedokteran Universitas Indonesia yang telah melaksananakan progress test dua kali setiap tahun. ${ }^{4}$

\section{KESIMPULAN}

Progress test telah berhasil dilaksanakan pada minggu pertama blok ketiga semester ganjil TA 2013/2014. Progress test yang terdiri dari 200 soal, diikuti oleh 200 mahasiswa yang dipilih secara random. Hasil progress test menunjukan adanya peningkatan nilai rata-rata ujian dari mahasiswa Tahun 1 sampai Tahun 4 yang konsisten dengan tingkat pemahaman materi kuliah setiap angkatannya. Analisis butir soal menunjukan sebaran tingkat kesukaran yang cukup baik, dimana sebagian besar berada dalam level sedang.

\section{SARAN}

Penelitian ini masih mempunyai beberapa kelemahan. Untuk mendapatkan gambaran profil mahasiswa yang lengkap disarankan untuk melaksanakan progress test ini secara berkelanjutan setiap tahunnya, yang diikuti oleh semua mahasiswa, sehingga perkembangan tingkat pemahaman setiap mahasiswa dapat dipantau secara terus menerus. Progress test sebaiknya dilakukan di akhir semester ganjil agar setiap angkatan mendapat kesempatan mengukur pemahamannya terhadap materi selama proses pembelajaran dari tahun pertama sampai menjelang akhir pendidikan kedokteran.

\section{UCAPAN TERIMA KASIH}

Pada kesempatan ini kami sampaikan ucapan terima kasih kepada segenap pimpinan Dekanat Fakultas Kedokteran YARSI yang telah memberikan dukungan moril maupun materil untuk dapat menyelesaikan penelitian ini tepat pada waktunya. Ucapan terima kasih juga penulis sampaikan kepada para pengampu Blok dan Koordinator Blok Fakultas kedokteran Universitas YARSI. Terima kasih penulis ucapkan juga kepada mahasiswa yang telah terpilih sebagai subyek penelitian dan pihak-pihak lain yang telah membantu sehingga penelitian ini dapat terlaksana. Tidak lupa juga kami mengucapkan terima kasih yang setulusnya kepada Direktorat Pendidikan Tinggi yang telah memberikan dana melalui program HPEQ tahun 2012 untuk terlaksananya penelitian ini.

\section{DAFTAR PUSTAKA}

1. Rushton A. Formative assessment: a key to deep learning? Medical Teacher. 2005; 27( 6):509-13.

2. Van Der Vleuten C.P.M, Verwijnen G.M, Wijnen W.H.F.W. Fifteen Year of Experience with progress testing in a problem-based learning curriculum. Medical Teacher. 1996;18(2):103-9. 
3. Manoppo, FP. The Impact of Formative Assesment on The Student Responses to The Module and Sumative Assessment in The Medical Faculty of Sam Ratulangi University Manado. Jurnal PERPIPKI. 2011.No. 2: 32-41.

4. Al Alwan I, Al-Moamary M, Al-Attas N, Al Kushi A, AlBanyan E, Zamakhshary M, et al. The Progress Test as a Diagnostic Tool for a New PBL Curriculum. Education for Health. 2011. 24:1-10

5. Oldham J. Formative Assessment for Progress Tests of Applied Medical Knowledge; The Role of the Student. From the REAP International online Conference on Assessment Design for Learner Responsibility, 29th-31 st May, 2007 [cited 2012 Juni 28]. Available from: http://ewds.strath.ac.uk/REAP07

6. McHarg J, Bradley P, Chamberlain S, Ricketts C, Searle J, McLachlan JC. Assessment of Progress Tests. Medical Education. 2005;39: 221-7.

7. Menaldi, SL, Werdhani, RA, dan Mardiastuti, HW. Hubungan Antara Hasil Uji Psikometrik Mahasiswa dan Skor Progress Test di Fakultas Kedokteran Universitas Indonesia. Jurnal PERPIPKI. 2012. No 3: $15-9$. 